\author{
JULIA M. MURRMANN \\ Uniwersytet Warszawski, Warszawa \\ ORCID: 0000-0003-0043-6640
}

\title{
RODZINNA POLITYKA JĘZYKOWA. STRATEGIE KOMUNIKACYJNE W WYCHOWYWANIU DZIECI TRÓJJĘZYCZNYCH
}

Słowa kluczowe: wielojęzyczność, kompetencje lingwistyczne, rodzinna polityka językowa, strategie komunikacyjne, edukacja trójjęzyczna/trzyjęzyczna/trilingwalna ${ }^{1}$.

\section{STRESZCZENIE}

Niektórzy rodzice, zmotywowani lub zmuszeni okolicznościami życiowymi, nie poprzestają na bilingwalnym wychowaniu, lecz wprowadzają trzeci (a niewykluczone, że nawet czwarty i kolejny) język do repertuaru językowego swoich dzieci. W specjalistycznej literaturze naukowej oraz poradnikowej poświęca się zagadnieniu symultanicznej akwizycji trzech języków oraz wczesnej ekspozycji na trzy języki mało miejsca, gdyż są to fenomeny znacznie mniej rozpowszechnione niż dwujęzyczne nabywanie kompetencji oraz edukacja bilingwalna. Na podstawie wywiadów z rodzicami dzieci trójjęzycznych w artykule przedstawiono strategie komunikacyjne wykorzystywane w wychowywaniu trzyjęzycznych dzieci, będące najczęściej specyficznymi adaptacjami znanych modeli wykorzystywanych w wychowywaniu bilingwalnym. Wyniki badań mogą zainteresować zarówno językoznawców, jak i rodziców zastanawiających się, jak poprowadzić proces wychowania wielojęzycznych dzieci.

\section{ROZWAŻANIA WSTĘPNE}

Wiele badań i doniesień naukowych pozwoliło obalić długo krążący mit o nadzwyczajnym charakterze wielojęzyczności jako cechy ludzkości. Wiadomo, że monolingwalizm to mniej rozpowszechniona forma, zarówno współcześnie, jak i historycznie, a większość populacji świata posługuje się więcej niż jednym językiem (Bhatia, Ritchie 2013: XXI; Edwards 2013: 14; Franceschini 2013: 5; Spolsky 1998: 51), choć należy też zaznaczyć, że istnieje wiele terminologicznych i metodologicznych nieścisłości, a także trudności w prowadzeniu badań oraz w definiowaniu wielojęzyczności (Cenoz 2013). W literaturze

\footnotetext{
${ }^{1}$ Zarówno w literaturze przedmiotu dotyczącej wielojęzyczności, jak i w słownikach języka polskiego występuje kilka wariantów przymiotnika odnoszącego się do współwystępowania lub używania trzech języków: trójjęzyczny, trzyjęzyczny oraz — chyba najmniej rozpowszechniony — trilingwalny (jako kalka $\mathrm{z}$ angielskiego trilingual). Wszystkie terminy są prawidłowe i mogą być stosowane zamiennie.
} 
specjalistycznej proponuje się mianowicie szereg podziałów wielojęzyczności opierających się na różnych kryteriach, takich jak:

— kryterium „głębokości” znajomości języka i zakresu kompetencji językowej (uwzględniające to, jaki stopień biegłości w poszczególnych językach zaliczanych do repertuaru językowego jednostka reprezentuje);

- kryterium wieku akwizycji językowej, czyli czasu nabycia kompetencji językowej, odnoszące się do tego, w którym momencie ontogenezy jednostka zaczęła przyswajać język;

— kryterium sposobu akwizycji języka i typu socjalizacji do danego języka;

— kryterium stosunku emocjonalnego do języków;

— kryterium rozwoju i organizacji kognitywnej, ustalane na podstawie obserwacji relacji język - myślenie;

— kryterium jakościowe - funkcjonalne (uwzględniające różny prestiż i trwałą dyferencjację funkcji społecznych w zależności od sfery życia, domeny i kontekstu społecznego);

— kryterium zasięgu;

— kryterium ilościowe dotyczące liczby języków, którymi włada jednostka².

W tym kontekście należy podkreślić, że niektórzy badacze, np. Anat Stavans i Charlotte Hoffmann (2015), wręcz nalegają, by rozdzielać rozważania na temat dwujęzyczności od rozważań nad wielojęzycznością (która według nich zachodzi dopiero w przypadku trzech lub więcej języków w repertuarze lingwistycznym jednostki bądź społeczności), argumentując, że „trzyjęzyczne jednostki (lub osoby posługujące się więcej niż trzema językami) zasługują na szczególną uwagę zarówno pod kątem badań nad nabywaniem i używaniem trzech (lub więcej języków) z perspektywy jednostkowej, jak i uwzględniając szersze socjolingwistyczne ujęcie" (Stavans, Hoffmann 2015: 1). Jest to zapewne częściowo uzasadnione podejście, niemniej jednak wydaje się, że wiele badań dotyczących komunikowania językowego, akwizycji kompetencji lingwistycznych, korzyści wynikających z wielojęzyczności, metod nauczania itd. można z powodzeniem prowadzić, stosując podstawową opozycję ,jednojęzyczność wielojęzyczność" i traktując wielojęzyczność jako pojęcie nadrzędne, obejmujące dwujęzyczność, trzyjęzyczność oraz posługiwanie się jeszcze większą liczbą języków (Aronin, Singleton 2008; Cenoz 2013; Murrmann 2018). Niniejszy artykuł poświęcony jest jednak rozważaniom nad wielojęzycznością w tym bardziej wyspecjalizowanym rozumieniu, tak jak definiują ją Stavans i Hoffmann (2015), gdyż chodzi o trilingwalne wychowanie dzieci.

Współcześnie prowadzi się wiele badań dotyczących wielojęzyczności, przy czym w większości przypadków naukowcy, będący notabene przedstawicielami różnych nauk - humanistycznych, społecznych, kulturowych, psychologicznych,

\footnotetext{
${ }^{2}$ Szersze, zbiorcze omówienie różnych rodzajów wielojęzyczności i ich charakterystykę, przygotowane na podstawie dorobków wielu autorytetów w tej dziedzinie, można znaleźć w opracowaniu Julii Murrmann (2014).
} 
medycznych itd., koncentrują się na najbardziej rozpowszechnionej formie wielojęzyczności, jaką jest dwujęzyczność. Nie sposób przedstawić tu wszystkich kierunków i perspektyw badawczych, ale wymieńmy kilka najważniejszych dziedzin: wpływ bilingwizmu na działanie mózgu, myślenie oraz rozwój procesów poznawczych (Bialystok 2001; Stavans, Hoffmann 2015), w tym interesujące badania sugerujące pozytywne skutki dwujęzyczności w procesie zdrowego starzenia się poznawczego i jej ochronne działanie przeciwko demencji (Atkinson 2016; Bialystok, Craik, Ryan 2006; Bialystok, Luk, Craik 2009; Bialystok, Luk, Craik, Grady 2011; Bialystok, Schweizer, Ware, Fischer, Craik 2010; Bialystok, Sullivan 2017); związki między językiem a myśleniem u dwujęzycznych osób i procesy przetwarzania językowego (Flora 2010; Leva 2011; Jarvis, Pavlenko 2008; Pavlenko 2014); wielojęzyczna i wielokulturowa tożsamość (Molinelli 2017); aspekty akwizycji dwujęzycznej (Yip, Matthews 2007; Grosjean, Ping 2013; Aronin, Singleton 2012; Burck 2007); wielojęzyczność widziana przez wpływ stosunków władzy na kształtowanie polityki językowej w skali makro i mikro (Blackledge, Creese 2010) oraz wieloaspektowe badania nad wielojęzycznością „w nowej perspektywie ważnej dla rynku światowego, a mianowicie w świetle zjawisk internacjonalizacji i globalizacji, które nabrały istotnego tempa w sferze ekonomicznej" (Stavans, Hoffmann 2015: 6).

Jeżeli chodzi o obszerną literaturę dotyczącą nabywania kompetencji językowych, to także w tym wypadku należy podkreślić, że zdecydowana większość publikacji dotyczy bilingwizmu. Jednocześnie (i konsekwentnie) gros pozycji na rynku z cyklu poradników (ang. handbook, manual, compendium, self-help book) i przewodników (ang. guide) jest skierowana do rodziców dzieci dwujęzycznych. Kultową lekturą („,biblią” dla rodziców wychowujących dwujęzycznie dzieci) jest książka George'a Saundersa (1982) Bilingual children: guidance for the family, w której autor - nauczyciel języka niemieckiego w Australii — opisał, na podstawie doświadczeń zdobytych we własnej rodzinie, jak wychował troje dwujęzycznych dzieci. Oczywiście od tego czasu, tj. od lat 80. XX w., tematyka doczekała się pogłębionej refleksji naukowej i wielu systematycznych badań owocujących teoriami i ugruntowaną metodyką (Zurer, Pearson 2008; King, Mackey 2009; Barron-Hauwaert 2011; Baker 2014). Ponadto na rynku dostępne są także liczne poradniki napisane oraz wydane przez samych rodziców (a zatem bez fachowej redakcji, oraz takie, które nie ukazały się pod auspicjami renomowanych wydawnictw) tu na uwagę zasługuje ciekawa i zabawna książka Anniki Bourgogne (2014) Be Bilingual. Practical Ideas for Multilingual Families, w której Finka, nauczycielka angielskiego, opowiada o ,językowej przygodzie" swoich dwujęzycznych córek — Emmy i Sary. Nie zmienia to jednak tego, że znacznie mniej pozycji dotyczy wielojęzycznego (ukierunkowanego na więcej niż dwa języki; tu faktycznie należy uwypuklić rozróżnienie Stavans i Hoffmann) wychowania potomstwa, choć w ostatnich latach temat ten zyskuje na znaczeniu i popularności. Na szczególną uwagę w tym kontekście zasługują prace naukowe Xiao-lei Wang, badaczki, matki dwojga trójjęzycznych dzieci. Wang zgłębiła tematykę akwizycji językowej na wczesnym etapie rozwoju dzieci, od urodzenia do 11. roku życia — głównie na podstawie wieloletniej obserwacji przebiegu akwizycji 
chińskiego, francuskiego oraz angielskiego (USA) przez własnych synów: Léandre’a i Dominique'a (2008) - a także w wieku nastoletnim, kiedy największym wyzwaniem jest równomierne utrzymanie znajomości poszczególnych języków na poziomie biegłości (2016), ponadto podjęła tematykę nauczania czytania i pisania w przypadku dzieci wielojęzycznych (2011).

Zespół badaczy w składzie: Julia Festman, Gregory J. Poarch i Jean-Marc Dewaele (2017), którzy sami są wielojęzyczni, wychowują wielojęzycznie własne dzieci oraz prowadzą badania naukowe w zakresie wielojęzyczności, przygotował akademicki poradnik oparty na historiach trzech znacznie różniących się gospodarstw domowych i udowodnił, że nie ma one fit solution for multilingual parenting, czyli jednej recepty, jak wychować wielojęzyczne dzieci.

Natomiast Andreas Braun i Tony Cline (2014) na podstawie badań w dwóch europejskich krajach (Niemczech i Wielkiej Brytanii) zgłębili tematykę trzyjęzycznej edukacji dzieci, trudności funkcjonowania w trójjęzycznej rodzinie w przeważnie jednojęzycznych społeczeństwach oraz sformułowali tezę o pojawianiu się zjawiska „nowej trzyjęzyczności” (ang. new trilingualism) wśród dzieci dobrze wykształconych, zamożnych i zajmujących wysokie stanowiska rodziców jako konsekwencji globalnych trendów migracyjnych i ekspansji Unii Europejskiej.

\section{ZAŁOŻENIA METODOLOGICZNE BADAŃ WLASNYCH}

Celem artykułu było przedstawienie strategii komunikacyjnych wykorzystywanych przez rodziców dzieci trójjęzycznych. Główne pytanie badawcze dotyczyło rodzinnej polityki językowej w przypadku wychowywania dzieci mówiących trzema językami, a szczegółowe pytania badawcze obejmowały takie kwestie jak: kto (który rodzic lub dodatkowa osoba przebywająca w gospodarstwie domowym) rozmawia z dzieckiem/ dziećmi w jakim języku (z uwzględnieniem rodzaju kompetencji użytkownika danego języka); w jakich okolicznościach używane są języki obecne w życiu rodziny i czym są motywowane określone zachowania językowe; jak radzą sobie dzieci — w opinii rodziców - $\mathrm{z}$ wielojęzycznością; czy rodzice korzystają z jakiegoś rodzaju pomocy w trilingwalnej edukacji potomstwa i jeśli tak, to o jakie wsparcie chodzi; jakie są zalety i wady stosowanej w domu rodzinnej polityki językowej oraz jakie są ich konsekwencje dla pozajęzykowego życia rodziny.

Materiał badawczy zbierano w okresie od stycznia 2017 do marca 2019 r. O rodzinnej polityce językowej opowiedziało łącznie 128 rodzin, z czego prawie 40 wywiadów przeprowadzono osobiście $(\mathrm{n}=39)$, a w pozostałych przypadkach nawiązano kontakt $\mathrm{z}$ informatorami internetowo, przez tematyczne grupy w mediach społecznościowych $(\mathrm{n}=85)$ oraz dzięki zawarciu wirtualnej znajomości z osobami prowadzącymi blogi poświęcone wielojęzycznej edukacji własnych dzieci $(n=4)$. Badani różnią się między sobą pod wieloma względami: narodowością, etnicznością, kulturą, wiekiem, poziomem wykształcenia ogólnego i biegłości językowej, pozycją społeczną, wykonywanym zawodem, kompozycją rodziny (w tym liczbą i wiekiem potomstwa), używanymi w domu 
językami, aktualnym miejscem zamieszkania. Powyższych różnic nie należy traktować jako mankamentu lub potencjalnego źródła artefaktów: sytuacja każdej rodziny w przebadanej grupie jest po prostu inna (tak samo jak w rzeczywistości), co nie zmienia tego, że zdecydowano się na trójjęzyczne (lub wielojęzyczne) wychowanie dziecka (lub dzieci). Można wymienić kilka charakterystycznych cech występujących u znacznej większości rodzin, z którymi przeprowadzono wywiady (należy także podkreślić, że najczęściej informatorem była matka, $\mathrm{n}=124$ ): pełna rodzina (czasami nawet wielopokoleniowa, tzn. dziadkowie zamieszkują razem z dziećmi i wnukami), wielodzietność (rodziny z więcej niż jednym dzieckiem), czasowe lub stałe przebywanie na emigracji (np. na zagranicznym kontrakcie), mieszany etnicznie/narodowościowo charakter małżeństwa, dwujęzyczność lub wielojęzyczność jednego lub obojga rodziców, dobry stan zdrowia dzieci ${ }^{3}$.

\section{WYNIKI BADAŃ}

Nadanie czytelnych nazw poszczególnym strategiom komunikacyjnym przysporzyło wielu trudności. Nazwa metody, strategii, podejścia, modelu czy techniki ${ }^{4}$ powinna być stosunkowo krótka, „chwytliwa” (jeśli użyć kolokwialnego wyrażenia), być nośnikiem informacji, dobrze ilustrować i mieć w miarę możliwości wyjaśniający, tłumaczący (eksplikatywny) charakter. Wyodrębnione poniżej strategie komunikacyjne opierają się na znanych w literaturze przedmiotu metodach dwujęzycznego wychowania, które najczęściej funkcjonują, również wśród polskich badaczy, w oryginalnym angielskim brzmieniu (tłumaczenie na polski angielskiej terminologii jest często, także w tym przypadku, problematyczne).

\section{Rodzic — język oraz język otoczenia (ang. Parent - language and social environment)}

Jest to najbardziej popularna strategia komunikacyjna służąca trójjęzycznej akwizycji językowej w przebadanej grupie $(\mathrm{n}=81)$. To w pewnym sensie połączenie metody ,jeden rodzic — jeden język" (OPOL — one parent, one language lub rzadziej one person, one language) oraz metody ,język mniejszościowy w domu” (ML@H/MLAT —

\footnotetext{
${ }^{3} \mathrm{~W}$ badanej grupie odnotowano jeden przypadek samotnej matki wychowującej dwoje dzieci, 18 rodzin posiadających tylko (być może na razie) jedno dziecko, jedną rodzinę monoetniczną mieszkającą we własnym kraju, cztery przypadki dzieci ze stwierdzoną niepełnosprawnością lub spektrum zaburzeń rozwoju.

${ }^{4} \mathrm{~W}$ literaturze przedmiotu, w zależności od autora, używane są w kontekście nazwania sposobu (lub drogi) postępowania, mającego na celu osiągnięcie zamierzonego rezultatu (w tym przypadku: wychowanie dwujęzyczne), następujące terminy: metody (ang. methods), modele (ang. models), strategie (ang. strategies), podejścia (ang. approaches), techniki (ang. techniques). W niniejszym artykule preferuje się pojęcie „strategie komunikacyjne", choć inne terminy mogą być w niektórych kontekstach z powodzeniem używane synonimicznie.
} 
minority language at home $e^{5}$ ). Specyfika tej strategii, będącej de facto połączeniem dwóch popularnych metod wykorzystywanych w wychowywaniu dwujęzycznych dzieci, polega na tym, że w konkretnym domu używane są dwa języki mniejszościowe (jeden rodzic używa jednego języka, drugi rodzic drugiego języka; co także najczęściej oznacza, że rodzice nie mają jednego wspólnego języka ojczystego, gdyż są małżeństwem mieszanym), a z trzecim językiem (językiem większości) dziecko się styka, wchodząc $\mathrm{w}$ interakcje $\mathrm{z}$ otoczeniem społecznym: w placówkach oświatowych (przedszkole/szkoła), na placu zabaw lub na ulicy. Najczęściej każdy z języków przekazywany jest przez rodzimych użytkowników danego języka (matka, ojciec oraz otoczenie społeczne).

Strategia ta, w opinii stosujących ją rodziców, jest przyjazna dla rodziny, czytelna dla dzieci, łatwa do stosowania i bardzo skuteczna (dzieci są aktywnie trzyjęzyczne), pod warunkiem, że rodzice postępują z ,żelazną konsekwencją" (DOR ${ }^{6}$, NAT, ISA, HAN, KAT, SVE), że nie poddają się mimo okresowych trudności w myśl zasady „kropla drąży skałę" (BER) i motywują się nawzajem, nie bacząc na (często przejściowy) brak kooperacji ze strony dzieci (SOP, ANA, GIO). Sytuacje takie się zdarzają i jedyną dobrą strategią jest „przeczekanie kryzysu, bez zmiany strategii” (KAT).

Rodziny używające tej metody podkreślają, że problematyczna bywa komunikacja podczas wspólnych aktywności rodzinnych, tzn. sytuacji, w których razem przebywają różnojęzyczni rodzice oraz dzieci. Najczęstszym rozwiązaniem tego problemu okazuje się używanie w takich momentach jednego z języków (jest to także język, w którym tradycyjnie porozumiewają się między sobą małżonkowie; czasami jest to zdecydowanie jeden język; czasami używa się języka matki i ojca naprzemiennie; w innych przypadkach stosuje się język otoczenia, jeśli jest to jedyny wspólny język, którym władają rodzice). Stanowi to wprawdzie pewną niekonsekwencję, ale tylko wtedy możliwe są spontaniczne interakcje i miła atmosfera rodzinna (w innym przypadku konieczne jest stałe thumaczenie między językami, co zresztą stosują rodziny, które za wszelką cenę postanowiły rozgraniczać języki i nie zaburzać rytmu zasady: rodzic — język). W tabeli 1 przedstawiono przykładowe możliwe warianty rozwiązania problematycznej sytuacji wspólnej komunikacji rodzinnej stosowane przez badanych.

\footnotetext{
${ }^{5}$ Jest to model funkcjonowania typowy dla rodzin żyjących na emigracji — w domu używa się języka ojczystego (język mniejszości), podczas gdy dziecko w szkole oraz na ulicy styka się z innym językiem (językiem większości).

${ }^{6}$ Ze względu na rekomendowane kodowanie informacji o osobach badanych w celu zapewnienia im anonimowości w artykule użyto trzy (lub cztery w przypadku powtarzalności) pierwsze litery imienia informatora.
} 


\begin{tabular}{|l|l|l|l|l|}
\hline Język matki & Język ojca & $\begin{array}{l}\text { Język } \\
\text { otoczenia }\end{array}$ & $\begin{array}{l}\text { Język } \\
\text { wspólnych } \\
\text { aktywności } \\
\text { rodzinnych }\end{array}$ & Komentarz \\
\hline włoski (JUL) & $\begin{array}{l}\text { niemiecki } \\
\text { (ALE) }\end{array}$ & $\begin{array}{l}\text { angielski } \\
\text { (USA) }\end{array}$ & niemiecki & $\begin{array}{l}\text { Wybrano język ojca, gdyż Julia płynnie } \\
\text { posługuje się niemieckim, natomiast } \\
\text { Alexander zna tylko podstawy języka żony. } \\
\text { Para posługiwała się językiem niemieckim } \\
\text { także przed powiększeniem rodziny i po- } \\
\text { siadaniem potomstwa. }\end{array}$ \\
\hline $\begin{array}{l}\text { włoski } \\
\text { (GIO) }\end{array}$ & $\begin{array}{l}\text { arabski } \\
\text { (FIR) }\end{array}$ & $\begin{array}{l}\text { angielski } \\
\text { (USA) }\end{array}$ & włoski & $\begin{array}{l}\text { Wybrano język matki, gdyż jest to jedyny } \\
\text { język, którym mogą się porozumiewać } \\
\text { wszyscy. }\end{array}$ \\
\hline $\begin{array}{l}\text { polski } \\
\text { (AGA) }\end{array}$ & $\begin{array}{l}\text { niemiecki } \\
\text { (CHR) }\end{array}$ & $\begin{array}{l}\text { francuski } \\
\text { (Francja) }\end{array}$ & francuski & $\begin{array}{l}\text { Podczas konwersacji całej rodziny koniecz- } \\
\text { ne jest używanie francuskiego, gdyż jest } \\
\text { to jedyny język, w którym mogą swobodnie } \\
\text { porozumiewać się małżonkowie. }\end{array}$ \\
\hline $\begin{array}{l}\text { hiszpański } \\
\text { (MAR) }\end{array}$ & $\begin{array}{l}\text { angielski } \\
\text { (BEN) }\end{array}$ & $\begin{array}{l}\text { Arabski } \\
\text { (ZEA) }\end{array}$ & $\begin{array}{l}\text { hiszpański/ } \\
\text { angielski }\end{array}$ & $\begin{array}{l}\text { Podczas komunikacji rodzinnych używa } \\
\text { się naprzemiennie języków ojca i matki, } \\
\text { w równym stopniu znanych obojgu rodzi- } \\
\text { com (a także dzieciom) }\end{array}$ \\
\hline (PIE) & $\begin{array}{l}\text { angielski } \\
\text { (WB) }\end{array}$ & $\begin{array}{l}\text { niemiecki/ } \\
\text { francuski/ } \\
\text { angielski }\end{array}$ & $\begin{array}{l}\text { W tej rodzinie zdecydowano się na mie- } \\
\text { szane użycie wszystkich języków podczas } \\
\text { wspólnych aktywności rodzinnych, nawet } \\
\text { jeśli (lub właśnie z tego powodu) nie } \\
\text { wszyscy członkowie rodziny równomiernie } \\
\text { władają wszystkimi używanymi językami. }\end{array}$ \\
\hline
\end{tabular}

Tabela 1. Język wspólnej komunikacji rodzinnej w wielojęzycznych gospodarstwach domowych Źródło: badania własne.

Większość badanych mówiła o fenomenie uprzywilejowanej pozycji i emocjonalnej przewagi języka matki w stosunku do języka ojca, tzn. o lepszej znajomości przez dzieci języka matki oraz preferowaniu używania języka matki w codziennej komunikacji. Miałoby to wynikać ze specjalnej więzi emocjonalnej (o podłożu psychologicznym i biologicznym) matki z dzieckiem oraz roli, jaką odgrywa matka w pierwszych miesiącach i latach życia dziecka (karmienie piersią, opieka nad dzieckiem). Należy wystrzegać się ujęć stereotypowych i uprzedzeń genderowych, ale możliwe jest postrzeganie przez dzieci większej istotności komunikacji z matką niż z ojcem w pierwszych latach życia ${ }^{7}$. Wydaje się, że w wielu sytuacjach może jednak chodzić o fakt spędzania większej ilości

${ }^{7}$ Byłoby to spójne z wynikami badań pokazującymi, że większość dzieci silniej odczuwa strach separacyjny (ang. separation anxiety) w kontekście rozstania z matką niż z ojcem oraz że dzieci (w rodzinach pełnych) częściej mówią najpierw „mama”, a później „tata”. 
czasu aktywności dziecka z matką niż z pracującym ojcem. Efekt ten jest czasowy, co podkreślają rodzice starszych dzieci (3+).

Język społeczności (otoczenia), pod warunkiem wystarczającej ekspozycji na ów język, jest zazwyczaj szybko przyswajany. Dzieci wcześnie orientują się, że komunikacja w języku większościowym zapewni im więcej przyjaciół do zabawy. Nawet jeśli rodzina ma przyjaciół z dziećmi mówiącymi w językach mniejszości, tzn. w języku ojca i matki, i regularnie organizuje spotkania (ang. play dates), to jednak większość rówieśniczych dzieci przebywających dookoła posługuje się językiem większości (językiem otoczenia).

$$
\begin{gathered}
\text { Jedna osoba - jeden język } \\
\text { (ang. One person - one language) }
\end{gathered}
$$

Skoro mowa o trzyjęzyczności, a każda osoba używa tylko jednego języka, to oczywiste jest, że w danym gospodarstwie domowym muszą (na stałe lub przez istotną część czasu aktywności dziecka/dzieci) przebywać trzy osoby. Także ta metoda stanowi pewnego rodzaju adaptację OPOL-u, przy czym modyfikacja polega właśnie na pojawieniu się trzeciej osoby. W przebadanej grupie oprócz mamy i taty, którzy posługiwali się innymi językami, znajdowała się dodatkowa osoba używająca trzeciego języka: dziadek, babcia (czasem oboje) lub niania/opiekunka/au-pair/pomoc domowa/nauczyciel domowy/ prywatna nauczycielka (ang. home teacher), korepetytor/guwernantka ${ }^{8}$ (ang. tutor).

Strategia ta uważana jest przez użytkowników za bardzo efektywną (gdyż, jak mówi wiele matek, m.in. ALEX, KRI, ADR, EWA: „dzieci są jak gąbki”) i w opinii badanych ma liczne zalety: dziecko/dzieci ma(ją) jasność, z kim używa(ją) którego języka i nie czuje/ą się zagubione ani zakłopotane przy wyborze języka komunikacji; każda osoba kojarzona jest z innym językiem; czas ekspozycji na poszczególne języki jest — w ogólnym założeniu — równomiernie rozłożony; język przekazywany jest przez rodzimych użytkowników danego języka. W opinii badanych zmienianie kodu językowego (ang. code switching) nie stanowi dla dzieci żadnego problemu (mają jakby „wewnętrznie zakodowane” (EMI), z kim mówić w jakim języku, posiadają jakby „radar językowy”, jak określa to MARA). Sporadycznie pojawia się zjawisko mieszania języków (ang. code mixing), ale jest ono typowe dla wieku 2-4 lat. Pojawiające się próby odpowiadania w innym języku niż ten przynależny do danej osoby powinny być uprzejmie przerywane, należy również zachęcać dziecko do pilnowania zasady osoba-język, szczególnie w sytuacji rozmów tylko z jedną osobą. Celem tego konsekwentnego i spójnego systemu komunikacji jest wyrobienie nawyku i budowanie motywacji u dziecka oraz zapobieganie łączeniu lub mieszaniu języków.

Słabą stroną strategii także w tym wypadku jest utrudnione jednoczesne porozumiewanie się całej rodziny podczas wspólnych aktywności. Tu są możliwe różne warianty:

\footnotetext{
${ }^{8}$ To zapomniane słowo zdaje się powracać do dyskursu społecznego wraz ze wzrastającym znaczeniem zawodu guwernera w nowej odsłonie: elitarnej „niani”, posiadającej wykształcenie pedagogiczne i kompleksowo organizującej edukację i wszechstronny rozwój podopiecznych pod nieobecność rodziców.
} 
czasem konieczne jest stałe tłumaczenie wszystkich wypowiedzi, czasem nie: dorośli mogą znać bowiem inne języki używane w domu (choć nie używają ich w rozmowach z dziećmi) lub nie znać języka partnera albo „osoby trzeciej” (użytkownika tego trzeciego języka: teściów, opiekunki, pomocy domowej).

Pewien mankament zgłaszany przez rodziców (zwłaszcza starszych dzieci) wiąże się z tym, że w niektórych przypadkach znajomość trzeciego (lub drugiego i trzeciego) języka jest jedynie pasywna — dziecko rozumie, ale nie mówi z płynnością równą biegłości w pierwszym i drugim języku (lub w pierwszym języku). Różnice w kompetencji językowej mogą także dotyczyć nierównego zasobu słownictwa w poszczególnych językach. Są to więc obszary, w których trzeba więcej pracować z dziećmi, a przyszły sukces zależy od zaangażowania rodziców i dodatkowych osób.

\section{Jeden rodzic - dwa języki, drugi rodzic - trzeci język (ang. One parent - two languages, second parent - third language)}

Ze względu na to, że jeden z rodziców używa dwóch języków, w niniejszej strategii komunikacyjnej można odnaleźć pewne analogie do znanej metody dwujęzycznego wychowywania znanej pod nazwą „kontekst” (ang. context) lub „czas i miejsce” (ang. time and place), wykorzystywanej do wprowadzenia drugiego języka przez zmianę okoliczności — kontekstu, sytuacji, tematyki, czasu i miejsca — użycia języka, ale bez przypisywania konkretnego języka konkretnej osobie. Dla lepszej ilustracji: w formie klasycznej, w sytuacji dwujęzyczności, metoda ta jest wykorzystywana przez jednojęzycznych rodziców mieszkających w kraju, gdzie mówi się w ich języku ojczystym, przy czym rodzice ci niejako sztucznie stwarzają sytuacje, w których używa się innego języka, planuje i wykorzystuje wszelkie nadarzające się okazje do zapewnienia dziecku kontaktu z tym dodatkowym językiem. Mogą to robić samodzielnie (w określonych okolicznościach używać innego języka niż ojczysty ${ }^{9}$ ) lub organizując zajęcia/warsztaty/ lekcje albo wyjazdy do krajów, w których dany język jest w użyciu (także na obozy językowe). Natomiast programy szkół dwujęzycznych wykorzystujących to podejście są układane zgodnie z założeniem, że język wykładowy powinien się zmieniać w zależności od czasu i miejsca, w których odbywają się lekcje, przykładowo: rano zajęcia $\mathrm{w}$ jednym języku, a po południu — $\mathrm{w}$ drugim języku; albo np. przedmioty humanistyczne w jednym tygodniu w jednym języku, a w kolejnym — w drugim. Ponadto stosuje się dodatkowe zabiegi wzmacniające związek kontekstu z językiem, np. lekcje w różnych językach odbywają się zazwyczaj w innych pomieszczeniach klasowych — tak, aby zmieniały się czas i miejsce użycia języka.

${ }^{9}$ Językową rutynę można przerwać np. w cyklu tygodniowym — w dni powszednie używa się jednego języka, a w weekendy — drugiego. Niektóre rodziny stosują krótkie przerywniki w trybie codziennym np. podczas posiłku/posiłków rodzina rozmawia w innym języku lub w drodze do szkoły używa się jednego języka, a w drodze powrotnej ze szkoły — drugiego. Inne rodziny wybierają cykle roczne, co może przybrać następującą formę: jednym językiem posługują się w trakcie roku szkolnego, drugim podczas okresu wolnego od szkoły. 
$\mathrm{W}$ interesującym nas przypadku rodzin wychowujących dzieci trilingwalnie jeden $\mathrm{z}$ rodziców decyduje się na używanie w interakcjach z dziećmi dwóch języków. Sytuacja ta może być spowodowana jej/jego własną dwujęzycznością (,wrodzoną”, w tym sensie, że osoba ta sama dorastała od najmłodszych lat z dwoma językami) lub przekonaniem, że warto zainwestować w kolejny język w wychowaniu dziecka/dzieci. Pierwsza sytuacja odnosi się do dwóch matek, Hiszpanek, które oprócz hiszpańskiego (kastylijskiego) uczą swoje dzieci również języków lokalnych (katalońskiego), ojca Szwajcara oprócz niemieckiego Hochdeutsch uczącego swoje córki także schwyzertüütsch, dwujęzycznej matki Kanadyjki (angielski-francuski) oraz dwujęzycznego ojca Szweda/Fina (szwedzki-fiński). W drugim przypadku mamy do czynienia z rodzicami $(n=7)$, którzy nie są native speakerami, ale oprócz języka ojczystego wprowadzają drugi język, gdyż sami nim biegle władają. Najczęściej dotyczy to nauczycieli tego języka — angielskiego, francuskiego, niemieckiego, hiszpańskiego (warto zwrócić uwagę na wysoką wartość komunikacyjną tych języków).

Używanie języka nierodzimego może budzić pewne kontrowersje, ale w dzisiejszych czasach rodzice decydujący się na takie przedsięwzięcie mają do dyspozycji, jak sami podkreślają, liczne środki pomocnicze: łatwy dostęp do obcojęzycznej literatury, obcojęzyczną telewizję, internet z nieskończoną ilością materiałów audiowizualnych oraz możliwość licznych (łatwiejszych do zorganizowania niż w przeszłości) zagranicznych wyjazdów.

Choć trudno w przypadku tak niejednorodnej grupy mówić o typowych dla tego podejścia cechach, to jednak można odnaleźć w zachowaniach rodziców elementy charakterystyczne dla strategii „,kontekstu/czasu i miejsca”. Klasyczną porą na wprowadzenie drugiego języka są np. posiłki, dojazdy do szkoły, wieczorne czytanie książki (ang. pijama story time) lub/i pogawędki przed snem (ang. crib talk, pillow talk, bed talk, goodnight talk), wyjazdy zagraniczne lub docelowe lekcje/zajęcia w dodatkowym języku. Innym typowym czynnikiem wyzwalającym używanie drugiego języka jest pojawienie się dodatkowej osoby, która zna np. tylko ten ,inny” język (członek rodziny lub przyjaciel).

Niektórzy rodzice decydują się na mówienie większości kwestii (szczególnie do małych dzieci) w dwóch językach jednocześnie, tzn. na powtarzanie każdej wypowiedzi (słowa lub zdania) najpierw w jednym języku, a później w drugim. Jest to przedsięwzięcie czasochłonne i z pragmatycznego punktu widzenia można podać w wątpliwość, czy dziecko słucha i przyswaja także komentarze i polecenia w drugim języku (od momentu, kiedy zorientowało się, że druga część jest tłumaczeniem pierwszej). Niemniej jednak w opinii matki i ojca stosujących tę metodę $(n=2)$ dzieci rozumieją (pasywnie) i używają (aktywnie) słownictwa w obu językach.

$$
\begin{gathered}
\text { Dom - otoczenie - szkoła } \\
\text { (ang. home - social environment - school) }
\end{gathered}
$$

Niektóre badane rodziny przebywają lub przebywały na kontraktach zagranicznych (w znacznej większości ojciec/mąż był czasowo wysyłany do pracy w zagranicznej filii firmy), czyli byli/są tzw. ekspatami (ang. expats). W zależności od kraju, w którym 
przebywają, do życia rodziny wprowadzany jest drugi lub nawet trzeci język (może chodzić o kraje dwujęzyczne lub o kraje nieanglojęzyczne, w których ekspaci wielokrotnie korzystają z różnego typu placówek skierowanych do zagranicznych gości, gdzie wszyscy posługują się współczesną lingua franca, czyli angielskim). Żeby lepiej zilustrować tę sytuację, podajmy kilka przykładów:

— niemiecka para ANK i BER wyjechali na kontrakt do Brazylii, a ich dzieci, PAU (5) i MIA (3), uczęszczali do anglojęzycznego przedszkola (rodzice w domu posługują się niemieckim, dzieci używają dodatkowo portugalskiego i angielskiego);

— niemiecka para BRI i PET spędzili kilka lat w Chinach, a ich dzieci, RON (16) i ROB (14), odbyli edukację w brytyjskiej szkole (rodzice w domu używają niemieckiego, dzieci dodatkowo chińskiego i angielskiego);

- polska para MAT i ANN mieszkają od kilkunastu lat w RPA, a ich synowie, ROB (13) i SEB (9), uczą się w dwujęzycznej szkole w Kapsztadzie (rodzice w domu używają polskiego, a dzieci dodatkowo angielskiego i afrikaans; przy czym w RPA funkcjonuje kilkanaście języków urzędowych i dzieci miały z nimi sporadyczną styczność).

Rodzice zwracają uwagę na problematyczne kwestie takie jak mniejszy zasób słownictwa (szczególnie specjalistycznego, np. w zakresie geografii, biologii, chemii, fizyki) w języku używanym w domu, częściowe mieszanie języków (ang. code mixing), zwłaszcza w zakresie syntaktyki, trudności z wyrażaniem uczuć i emocji w języku rodziców, braki we frazeologii ogólnej, a także nieznajomość języka młodzieżowego, tj. języka rówieśników (którego rodzice nie znają lub nie używają z racji różnicy pokoleniowej).

Mieszane używanie języków

(ang. Mixed use of languages)

Sytuację tę porównać można na poziomie mikrospołecznym do makrospołecznych zjawisk typu wielojęzyczność społeczna lub poliglosja (wynikające ze współistnienia większej liczby języków urzędowych lub języków i dialektów w danej społeczności). Rodzina sama decyduje, w jakich sytuacjach używać danego języka: może być to układ zaplanowany (rzadziej) lub w pełni spontaniczny (częściej). Podejście to daje wielojęzycznej rodzinie pełną wolność i nieograniczone możliwości. Sprawia wręcz wrażenie „zabawy z językami”. W ramach tej w niewielkim stopniu skodyfikowanej metody mogą pojawiać się elementy innych znanych metod, używanych naprzemiennie lub okresowo: OPOL, MLAH, context/time and place. Obserwatorowi z zewnątrz może się wydawać, że w komunikacji rodzinnej nie obowiązują żadne zasady, ale jest to zazwyczaj złudne: żeby zapewnić dzieciom wystarczająco długi i intensywny czas ekspozycji na każdy język, musi istnieć jakaś kontrola (często nieformalna) ze strony rodziców. Należy też podkreślić, że stosowanie tej metody dotyczy rodzin ze starszymi dziećmi, a zatem tych, które są już bardziej doświadczone i znajdują się na dalszym etapie wychowania dzieci. Najczęściej rodziny te stosowały wcześniej inną strategię (jedną z dotychczas wymienionych), ale nie sprawdziła się ona na dłuższą metę. Po próbach 
zakończonych niepowodzeniem przyjęto zatem inną strategię — zdeklarowany brak jednolitej techniki, zdejmujący presję i pozwalający na przyjemne spędzanie czasu razem jako rodzina. Nie bez znaczenia jest to, że wiele się zmienia w zachowaniu (ogólnym oraz językowym) u dzieci w wieku szkolnym (kiedy wzrasta rola grupy rówieśniczej kosztem znaczenia pozycji rodziców).

Przy okazji omawiania tej strategii należy zwrócić uwagę na pewien ciekawy fenomen, zaobserwowany przez wielu rodziców, który można nazwać ,językowym sprzężeniem zwrotnym" - im większą łatwość będzie sprawiało dziecku mówienie w danym języku, tym chętniej i częściej będzie go używało. Tu pojawia się niebezpieczeństwo porzucenia któregoś z języków (tego, który przychodzi dzieciom najtrudniej) i — o ile rodzice nie zastosują środków zaradczych mających na celu zwiększenie ekspozycji i ułatwienie jego używania — ,trudny” język może zejść na dalszy plan. Jednocześnie pokazywanie dzieciom, jak wartościowe, ciekawe, przyszłościowe i cool (używając języka młodzieżowego) jest biegłe władanie wieloma językami, wydaje się mocnym argumentem i bodźcem do używania wielu języków.

\section{ZAKOŃCZENIE}

W wielu rodzinach okoliczności życiowe sprawiają, że znajdujący się w różnych sytuacjach rodzice chcą — lub muszą — wprowadzić trzeci (lub nawet czwarty i kolejny) język do repertuaru językowego swoich dzieci już we wczesnym stadium ontogenezy. W specjalistycznej literaturze naukowej oraz poradnikowej poświęca się zagadnieniu symultanicznej akwizycji trzech języków oraz wczesnej ekspozycji na trzy języki mało miejsca, gdyż są to fenomeny znacznie mniej rozpowszechnione niż dwujęzyczne nabywanie kompetencji oraz edukacja bilingwalna (choć należy podkreślić, że tematyka ta systematycznie zyskuje na aktualności i popularności). Celem artykułu było przedstawienie strategii komunikacyjnych wykorzystywanych w wychowywaniu dzieci trzyjęzycznych, z uwzględnieniem zalet i wad, na które wskazywali badani rodzice, oraz motywów, jakimi się kierowali przy wyborze rodzinnej polityki językowej. Niektórzy rodzice korzystali z profesjonalnej pomocy w zakresie przygotowania do wielojęzycznego wychowywania (szkolenia lub konsultacje z glottodydaktykami, językoznawcami lub logopedami), inni zakupili fachową literaturę (podręczniki lub przewodniki poświęcone głównie bilingwalnej edukacji dzieci), w której szukali inspiracji, a jeszcze inni samodzielnie zaplanowali proces symultanicznej lub wczesnej akwizycji kilku języków przez własne dzieci.

Na podstawie przeprowadzonych badań na 128 rodzinach trzyjęzycznie wychowujących potomstwo wyróżniono następujące modele językowego funkcjonowania rodzin wielojęzycznych ${ }^{10}$ :

— rodzic — język oraz język otoczenia $(n=81)$;

— jedna osoba — jeden język $(n=23)$;

${ }^{10}$ Zdecydowano się przedstawić tutaj ujęcie ilościowe, żeby zilustrować częstość występowania danej kategorii strategii w przebadanej grupie, ale należy pamiętać, że badanie miało charakter jakościowy. 
— jeden rodzic — dwa języki, drugi rodzic — trzeci język $(\mathrm{n}=12)$;

— rodzice - otoczenie - szkoła $(\mathrm{n}=8)$;

- mieszane używanie języków $(n=4)$.

Są to podstawowe kategorie strategii komunikacyjnych i należy pamiętać, że realizuje się je z pewnymi modyfikacjami (i odstępstwami) w zależności od uwarunkowań wewnętrznych w danym gospodarstwie domowym. Rodzinna polityka językowa zależy od bardzo wielu czynników i badani często podkreślali, że to, co dobrze sprawdza się $\mathrm{w}$ ich gospodarstwie domowym, nie zawsze funkcjonuje w innym domu - np. u ich znajomych (nawet jeśli dla obserwatora z zewnątrz układ rodziny i jej sytuacja życiowa mogą wydawać się podobne). Badane rodziny deklarowały trzymanie się wybranego podejścia i konsekwencję w działaniu, ale podkreślały, że nie zawsze jest to możliwe $\mathrm{z}$, przyczyn życiowych”.

Ciekawą kwestią, którą jednak poruszymy tu tylko marginalnie — o tyle, o ile jest to ważne dla życia rodzinnego — jest także porozumiewanie się rodzeństwa między sobą. W procesie akwizycji języka ważne są rozmowy rodzic — dziecko, ale od pewnego momentu ważną funkcję należy przypisać również konwersacjom między rodzeństwem, szczególnie w wieku szkolnym. Zauważono, że w zdecydowanej większości przypadków rodzeństwo porozumiewa się między sobą (bez obecności rodzica) w języku otoczenia lub w języku ogólnorodzinnym.

Przeprowadzone badanie nie pozwala niestety na miarodajną ocenę efektywności wykorzystywanych strategii komunikacyjnych, głównie ze względu na zróżnicowany wiek dzieci — nie można porównywać kompetencji dwulatków, pięciolatków, młodzieży szkolnej i licealnej. Często rodzice małych dzieci (2-4 lata) są usatysfakcjonowani rezultatami wychowania lub wręcz ,zachwyceni” umiejętnościami językowymi dzieci, zapominając lub nie wiedząc, że to dopiero wiek szkolny stanowi najczęściej przełomowy i najtrudniejszy okres w wielojęzycznej edukacji (jak wynika z doświadczeń rodziców z dziećmi starszymi).

Niewątpliwie pojawienie się trzeciego języka w komunikacji rodziny jest czynnikiem utrudniającym proces wychowania językowego (tak samo, jak bardziej skomplikowane i trudniejsze jest dwujęzyczne wychowanie dzieci od jednojęzycznego), ale w opinii badanych okazuje się warte wysiłku i korzystne, mimo przejściowych trudności, gdyż jest „,inwestycją w przyszłość dzieci” (VER, NIC, HAN, JUS), „otwieraniem się na świat i wielokulturowość” (SIN, JUL, MARA, PETR), „myśleniem przyszłościowym" (ALEX, ANA, KAT, UTE, NAD) — badani różnorodnie określali pozytywy wielojęzycznego wychowywania dzieci, ale w ich wypowiedziach wyraźnie widać akcentowanie postępującej internacjonalizacji, globalizacji społecznej i ekonomicznej oraz wielokulturowości współczesnych społeczeństw. 


\section{BIBLIOGRAFIA}

Aronin L., Singleton D. 2008: Multilingualism as a new linguistic dispensation, International Journal of Multilingualism 5, 1-16.

Aronin L., Singleton D. 2012: Multilingualism, Amsterdam-Philadelphia: John Benjamins Publishing Company.

Atkinson A.L. 2016: Does Bilingualism Delay the Development of Dementia?, Journal of European Psychology Students 7(1), 43-50.

Baker C. 2014: A parents' and teachers'guide to bilingualism, Bristol-Buffalo-Toronto: Multilingual Matters.

Barron-Hauw aert S. 2011: Bilingual Siblings: Language Use in Families (Parents' and Teachers' Guide), Bristol-Buffalo-Toronto: Multilingual Matters.

Bhatia T.K., Ritchie W.C. 2013: Introduction, [in:] Bhatia T.K., Ritchie W.C. (eds.), The handbook of Bilingualism and Multilingualism, New York: Wiley Blackwell Publishing, XXI-XXIII.

Bialys tok E. 2001: Bilingualism in development: Language, Literacy, Cognition, Cambridge: Cambridge University Press.

Bialystok E., Craik F.I.M., Ryan J. 2006: Executive control in a modified anti-saccade task: Effects of aging and bilingualism, Journal of Experimental Psychology: Learning, Memory, and Cognition 32, 1341-1354.

Bialystok E., Luk G., Craik F.I.M. 2009: Cognitive Control and Lexical Access in Younger and Older Bilinguals, Journal of Experimental Psychology: Learning, Memory and Cognition 34(4), 859-873.

Bialystok E., Luk G., Craik F.I.M., Grady C.L. 2011: Lifelong Bilingualism Maintains White Matter Integrity in Older Adults, The Journal of Neuroscience 31(46), 16808-16813.

Bialystok E., Schweizer T.A., Ware J., Fischer C.E., Craik F.I.M. 2010: Bilingualism as a contributor to cognitive reserve: Evidence from brain atrophy in Alzheimer's disease, Cortex 48(8), 991-996. Bialystok E., Sullivan M.D. (eds.) 2017: Growing Old with Two Languages: Effects of Bilingualism on Cognitive Aging (Studies in Bilingualism), Amsterdam-Philadelphia: John Benjamins Publishing House. Blackledge A., Creese A. 2010: Multilingualism: A Critical Perspective, London: Continuum International. Braun A., Cline T. 2014: Language Strategies for Trilingual Families: Parent's perspectives, BristolBuffalo-Toronto: Multilingual Matters.

Burck C. 2007: Multilingual Living, Basingstoke: Palgrave Macmillan.

Cenoz J. 2013: Defining Multilingualism, Annual Review of Applied Linguistics 3, 3-18.

Edwards J. 2013: Bilingualism and Multilingualism: Some central conceptions, [in:] Bhatia T. K., Ritchie W.C.

(eds.), The handbook of Bilingualism and Multilingualism, New York: Wiley Blackwell Publishing, 5-25.

Franceschini R. 2013: History of multilingualism, [in:] Chapelle C.A. (ed.), The encyclopedia of applied linguistics, New York: Blackwell Publishing, 4-8.

Grosjean F., Ping L. (eds.) 2013: The psycholinguistics of bilingualism, Oxford: Wiley Blackwell Publishing. Festman J., Poarch G.J., Dewaele J.M. 2017: Raising multilingual children, Bristol-Buffalo-Toronto: Multilingual Matters.

Flora C. 2010: Double talk, Psychology Today 11/12, 70-80.

Jarvis S., Pavlenko A. 2008: Crosslinguistic influence in language and cognition, London: Routledge. King K., Mackey A. 2009: The bilingual edge. Why, when, and how to teach your child a second language, New York: Harper Collins. 
Leva B. 2011: How language shapes thought, Scientific America 304(2), 62-65.

Molinelli P. (ed.) 2017: Language and Identity in Multilingual Mediterranean Settings. Challenges for Historical Sociolinguistics, Berlin: Mouton De Gruyter.

Murrmann J. 2014: Wielojęzyczność jako źródło cierpień? Pozytywy i negatywy rozbudowanych kompetencji językowych z pespektywy społecznej i lingwistycznej, Socjolingwistyka 28, 29-47.

Murrmann J. 2018: Exploring aspects of raising multilingual first-born and later-born siblings from parents' perspective, Socjolingwistyka 32, 267-288.

Pavlenko A. 2014: The Bilingual Mind: And What It Tells Us About Language and Thought, New York: Cambrigde University Press.

Saunders G. 1982: Bilingual children: guidance for the family, Clevedon: Multilingual Matters.

Spolsky B. 1998: Sociolinguistics, Oxford: Oxford University Press.

Stavans A., Hoffmann Ch. 2015: Multilingualism. Key topics in sociolinguistics, Cambridge: Cambrigde University Press.

Wang X. 2008: Growing up with three languages: Birth to Eleven, Bristol-Buffalo-Toronto: Multilingual Matters.

Wang X. 2011: Learning to read and write in the multilingual family, Bristol-Buffalo-Toronto: Multilingual Matters.

Wang X. 2016: Maintaining three languages: The teenage Years, Bristol-Buffalo-Toronto: Multilingual Matters.

Yip V., Matthews S. 2007: The Bilingual Child: Early Development and Language Contact, Cambridge: Cambridge University Press.

Zurer Pearson B. 2008: Raising a bilingual child, New York: Living Language/Random House.

\begin{abstract}
Family language policy. Communication strategies in raising trilingual children

Keywords: multilingualism, language competences, family language policy, communication strategies, trilingual education.

Some parents, motivated or forced by circumstances of life, do not stop at a bilingual education, but introduce a third (or even another) language to their children's linguistic repertoire exposing them to trilingual (or multilingual) acquisition process. In the specialist literature and handbooks, as yet, there has been significantly less scientific exploration and scholarly attention dedicated to this field of study compared to the well researched bilingualism and dual language competences which are considerably more spread worldwide. Based on interviews with parents of trilingual children, the paper presents communication strategies used for raising trilingual children, which are often adaptations of well-known models used in bilingual education. The findings of the study may be of theoretical interest to linguists, and of practical interest to parents showing curiosity or concern about growing a multilingual family.
\end{abstract}

